調査・資料

\title{
PCR 法によるクワズイモの同定
}

(平成 28 年 7 月 20 日受理)

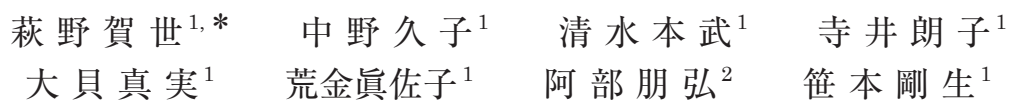

Identification of Alocasia odora (Kuwazuimo in Japanese) Using PCR Method

\author{
Kayo Hagino $^{1,}$ *, Hisako Nakano ${ }^{1}$, Motomu Shimizu ${ }^{1}$, Akiko Terai ${ }^{1}$, \\ Mami OGai ${ }^{1}$, Masako Aragane ${ }^{1}$, Tomohiro Abe ${ }^{2}$ and Takeo SAsamoto ${ }^{1}$ \\ ${ }^{1}$ Tokyo Metropolitan Institute of Public Health: 3-24-1 Hyakunin-cho, \\ Shinjuku-ku, Tokyo 169-0073, Japan; \\ ${ }^{2}$ Health and Safety Division, Bureau of Social Welfare and Public Health, Tokyo \\ Metropolitan Government: 2-8-1 Nishi-Shinjuku, \\ Shinjuku-ku, Tokyo 163-8001, Japan; \\ * Corresponding author
}

\begin{abstract}
Kuwazuimo (Alocasia odora) and shimakuwazuimo (Alocasia cucullata) are evergreen perennial plants that originated in East Asia. Although inedible, they are occasionally eaten by mistake because they resemble satoimo (Colocasia esculenta), and this has caused food poisoning in Japan. It is not easy to determine the cause of a food poisoning outbreak from the shape or chemical composition when the available sample is small. Therefore, we developed a new primer pair for PCR to identify kuwazuimo and shimakuwazuimo in small samples, based on the internal transcribed spacer (ITS) region of ribosomal DNA. Using PCR with the developed primer pair, we detected all samples of kuwazuimo obtained from the market, while excluding 17 other kinds of crops. The samples were identified as shimakuwazuimo by DNA sequencing of the PCR products. The present PCR method showed high specificity and was confirmed to be applicable to the identification of kuwazuimo and shimakuwazuimo from various crops.
\end{abstract}

(Received July 20, 2016)

Key words: 食中毒food poisoning; クワズイモAlocasia odora；シマクワズイモAlocasia cucullata; PCR 法PCR method; プライマー primer; 同定identification; リボソームDNA ribosomal DNA; ITS 領域 internal transcribed spacer region

\section{緒咅言}

クワズイモ（Alocasia odora）は東アジア原産のサトイ モ科クワズイモ属の常緑性多年草で, 食用であるサトイモ (Colocasia esculenta）に外観が類似しており（Fig. 1)， 誤認による捸食のため, 食中毒を引き起こすことが報告さ れている ${ }^{1) \sim 3)}$. クワズイモ属は， $20^{\circ} \mathrm{C}$ 以上の高温を好み， 多くは温室観葉植物として栽培されている。植物組織中に 水に難溶性のシュウ酸カルシウム $\left(\mathrm{CaC}_{2} \mathrm{O}_{4}\right)$ を含有し 誤って摂食すると，針状結晶による物理的な刺激により， 唇のしびれ，口腔内のはれ，胃痛を起こすことが知られて いる ${ }^{2,3)}$. 日本では，クワズイモは四国南部，九州南部以

\footnotetext{
* 連絡先 Kayo_Hagino@member.metro.tokyo.jp

1 東京都健康安全研究センター： T169-0073 東京都新宿区 百人町 3-24-1

2 東京都福祉保健局健康安全部： $7163-8001$ 東京都新宿区 西新宿 $2-8-1$
}

南に，シマクワズイモ（Alocasia cucullata）は琉球列島, 小笠原諸島に, ヤエヤマクワズイモ (Alocasia atropurpurea）は西表島に自生しており ${ }^{4)}$ ，このうちクワズイモ およびシマクワズイモの耐寒性は比較的高い5).

クワズイモの摂食が原因と疑われる食中毒が発生した場 合，原因特定のため，クワズイモの同定が必要である。摂 食した食品の残量が十分ある場合は，茎，根等の形態の比 較，顕微鏡によるシュウ酸カルシウムの針状結晶の確認が 可能であるが，残量が少ない場合や，調理加工品の場合 は，これらの方法による同定が困難なことがある。一方， $\mathrm{PCR}$ 等の分子生物学的手法が遺伝子組換え食品の検査等 で用いられている。近年では，リボソームDNAのinternal transcribed spacer（ITS）領域における塩基配列が近 縁種間でも異なることを利用したPCR法が開発され，植 物の鑑別に利用されている $\left.{ }^{6)}, 7\right)$ 。た植物だけでなく，キ ノコ類の鑑別に用いた報告もある ${ }^{8)}$ 。そこで，クワズイモ 

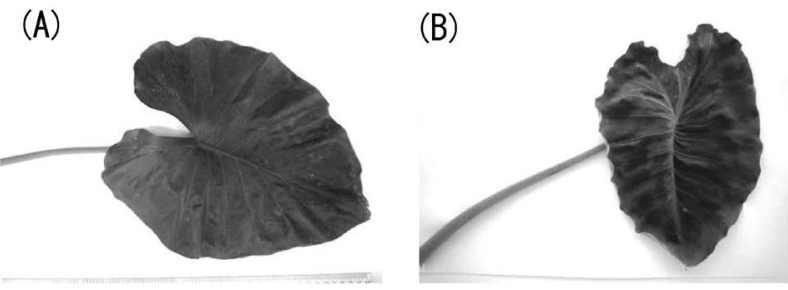

Fig. 1. Photographs of the leaves of (A) Alocasia odora (kuwazuimo) and (B) Colocasia esculenta (satoimo)

の摂食が食中毒の原因と疑われる際に, 食品残量が少ない 試料でも, クワズイモであることを同定する目的で PCR 法の検討を行ったので報告する.

\section{実 験方法}

1. 試料

クワズイモは 2013 年1月から 2016 年1月にかけて, 東 京都薬用植物園から入手した 1 試料, 東京都内拉よび埼玉 県内の小売店にて購入した鉢植え 4 試料を用いた。

PCR法の特異性を確認するため, サトイモ, ナス, ジャガイモ, ダイコン, コマツナ, ホウレンソウ, ニンジ ン, ゴボウ, タマネギ, ネギ, コメ, トウモロコシ, カボ チャ, サッマイモ, ナガイモ, キクイモ, シイタケから抽 出したDNAを用いて検討を行った。これらは農林水産省 統計*1を参考に出荷量の比較的多いもの, また名称の一 部にイモが含まれる農作物から 17 種類を選び東京都内お よび埼玉県内の小売店で購入した.

加熱処理実験には，クワズイモの根茎の皮をむき， $1.8 \mathrm{~cm}$ 立方（約 $8 \mathrm{~g}$ ）に切ったものを用いた.

\section{2. 装置}

高速冷却遠心機： Avanti ${ }^{\circledR}$ J-E (BECKMAN COULTER 社製), 微量高速冷却遠心機: CF15RN (日立工機社製), 分 光光度計：NanoDrop 2000c (サーモフイッシャーサイエン テイフイック社製)，サーマルサイクラー：GeneAmp ${ }^{\circledR} \mathrm{PCR}$ System9700 (Life Technologies 社製), 電気泳動装置: Mupid $^{\circledR}-2$ plus (アドバンス社製)，ゲル撮影装置：プリン トグラフ AE-6933FXES (アトー社製), DNAシークエン サー：Applied Biosystems ${ }^{\circledR}$ 3130xl ジェネティックアナ ライザー(Life Technologies社製)，超純水製造装置： Milli-Q integral 5 system (メルク社製) を使用した。

3. プライマー

クワズイモおよびシマクワズイモを検出するためのプラ イマーを作製した. National Center for Biotechnology Information（NCBI）の GenBankに登録されているクワ ズイモ，シマクワズイモのDNAの塩基配列（Acc. no.: AB429315, Acc. no.: AB429340）㧍よび両者と同じサ卜 イモ科であるサトイモのDNAの塩基配列（Acc. no.:

*1農林水産省農林水産統計http://www.maff.go.jp/j/tokei/ kouhyou/sakumotu/sakkyou_yasai/index.html
AY081000）を比較しリボソームDNAのITS1領域の一 部を特異的に増幅するプライマー対 (KUWAZU-Fb; 5'-CTC TCT CCC GTC CCT CG-3' お ょびKUWAZU-Ra; 5'-CGGGAGTCG TTCAGACTCG-3' 以下，クワズイモ 検出用プライマー対）を作製した。このプライマー対を使 用してPCRを行った場合，想定する増幅長はクワズイモ では $219 \mathrm{bp}$ ，シマクワズイモでは $215 \mathrm{bp}$ である。作製し たプライマー対の特異性を NCBI Blast検索にて, 確認し た.

また，各種農作物からのDNA抽出が確実にされている かを確認するために真核生物検出用プライマー対 (TR03； 5'-TCT GCC CTA TCA ACT TTC GAT GGT A-3' およびTR04; 5'-AAT TTG CGC GCC TGC TGC CTTCCT T-3') をPCRに用いた ${ }^{9)}$. プライマー合成はSIGMA-ALDRICH社に依頼した。

\section{DNAの抽出}

試料を約 $2 \mathrm{~mm}$ 立方に細切し, DNA抽出にDNeasy Plant Mini Kit（QIAGEN社製）を用いる場合は $0.1 \mathrm{~g}$, または，DNeasy Plant Maxi Kit（QIAGEN社製）の場合 は $1 \mathrm{~g}$ を採取しDNA抽出を行った。 DNA抽出はキット付 属の使用方法に従った。調製したDNA溶液は分光光度計 で波長 $260 \mathrm{~nm}$ の吸光度を測定し、濃度を算出後に実験に 供した。

\section{P C R}

$\mathrm{PCR}$ に供する溶液は， $10 \times \mathrm{PCR}$ 緩衝液（タカラバイオ 社製） $2.5 \mu \mathrm{L}, \mathrm{dNTPs}$ (タカラバイオ社製， $2.5 \mathrm{mmol} / \mathrm{L}$ ) $2 \mu \mathrm{L}$, EX Taq Hot Start Version（タカラバイオ社製） 0.2 $\mu \mathrm{L}, 6 \mu \mathrm{mol} / \mathrm{L}$ のフォードプライマーとリバースプライ マー各 $2.5 \mu \mathrm{L}$ ，打よび， $5 \mathrm{ng} / \mu \mathrm{L}$ に調製したDNA溶液を $2.5 \mu \mathrm{L}$ 加えた後, 脱イオン蒸留水 (ニッポンジーン社製, 遺伝子工学研究用）で $25 \mu \mathrm{L}$ になるように調製した. PCR は, $98^{\circ} \mathrm{C} 10$ 秒間, $60^{\circ} \mathrm{C} 30$ 秒間, $72^{\circ} \mathrm{C} 60$ 秒間を 1 サイ クルとして 30 サイクルで行った.

\section{6. 電気泳動}

$\mathrm{PCR}$ 産物は, エチジウムブロマイドを $0.5 \mu \mathrm{g} / \mathrm{mL}$ の濃度 になるように添加した $2.5 \%$ アガロースゲルおよび $1 \times$ TAE緩衝液を用いて電気泳動し, 紫外線照射 $(312 \mathrm{~nm})$ によりバンドの有無を確認した。

\section{7. 加熱処理}

購入したクワズイモの根茎（1.8 cm 立方, 約 $8 \mathrm{~g})$ を超 純水 $10 \mathrm{~mL}$ に浸し水煮 $\left(100^{\circ} \mathrm{C} 15\right.$ 分間㧍よび 30 分間）を 行った，超純水は超純水製造装置（メルク社製，電気抵抗 率 $17 \mathrm{M} \Omega \cdot \mathrm{cm}$ 以上）で製造したものを使用した．加熱後 の試料から DNA 抽出を行い, PCRを行った.

\section{DNA塩基配列解析}

$\mathrm{PCR}$ 後の溶液から, 余剩のプライマーおよび $\mathrm{dNTPs}$ ExoSAP-IT (Affymetrix社製) を用いて除去後, PCR 産物 を Big Dye ${ }^{\circledR}$ Terminator v3.1 Cycle Sequencing Kit (Life Technologies 社製）を用いて蛍光ラベル化した，未反応 の試薬を除去するため, エ夕ノール沈殿を行った，その 


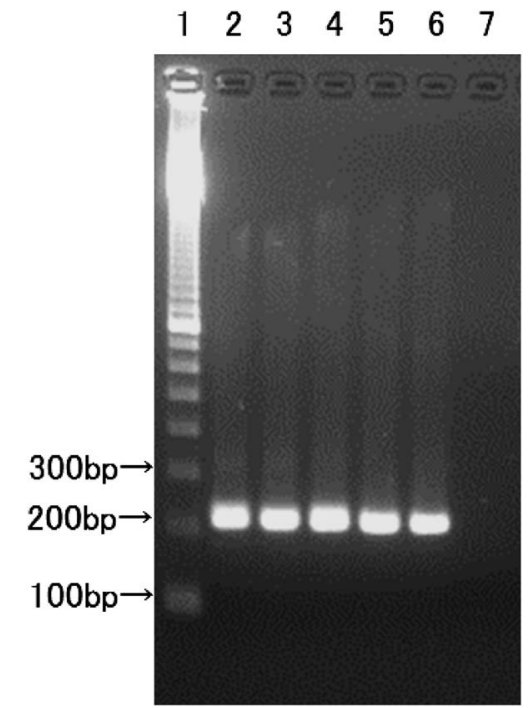

Fig. 2. Agarose gel electrophoresis of PCR-amplification products obtained using the primer pair, KUWAZU-Fb and KUWAZU-Ra

DNA was extracted from kuwazuimo for PCR. Lane $1: 100$ bp ladder marker; Lanes 2-6: kuwazuimo 1-5; and Lane 7: negative control (no template DNA).

後, 脱イオン化ホルムアミド（Life Technologies社製） を加え $95^{\circ} \mathrm{C} 3$ 分間変性した後, DNA シークエンサーによ り塩基配列の解析を行った ${ }^{* 2}$. 得られた塩基配列情報は Nucleotide BLASTで検索し, 種を判定した.

\section{結果および考察}

\section{PCR法による特異性の確認}

新規に作製したクワズイモ検出用プライマー対（KUWAZU-Fb/KUWAZU-Ra）を用いて，入手したクワズイ モ5試料から抽出したDNAを鋳型としてPCRを行った. その結果, クワズイモ検出用プライマー対を用いた PCR では，鋳型にクワズイモから抽出したDNAを用いた場合 に想定される増幅長のバンドを検出した（Fig. 2).

PCR法の特異性を確認するため, サトイモ, ナス, ジャガイモ, ダイコン, コマツナ, ホウレンソウ, ニンジ ン, ゴボウ, タマネギ, ネギ, コメ, トウモロコシ, カボ チャ, サツマイモ, ナガイモ, キクイモ, シイタケから抽 出したDNAを鋳型として, クワズイモ検出用プライマー 対を用いてPCRを行った。 その結果， 17 種類の農作物に ついて，バンドは検出されなかった（Fig. 3A）。またこれ らの農作物から DNAが抽出されていることを確認するた め, 抽出したDNAを鋳型として, 真核生物共通DNA配 列を検出するプライマー対（TR03,TR04）を用いて PCR を行った. その結果, 想定される増幅長 (137 bp）のバン ドが検出された (Fig. 3B). 以上の結果から, クワズイモ

\footnotetext{
*2 厚生労働省医薬品食品局食品安全部長通知, 輸入魚類加工 品のフグ種鑑別検查法について，食安輪発0906第 1 号，平 成 23 年 9 月 6 日
}
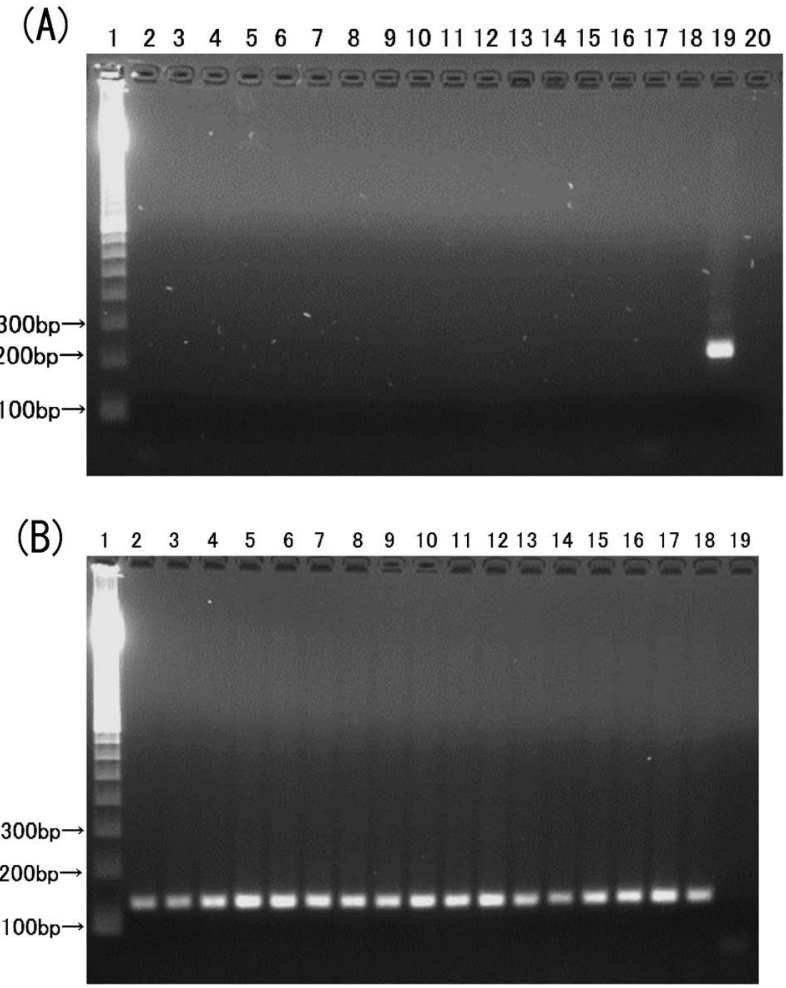

Fig. 3. Agarose gel electrophoresis of PCR-amplification products for various crops using the primer pairs (A) KUWAZU-Fb and KUWAZU-Ra and (B) TR03 and TR04

DNA was extracted from various crops for PCR. (A) Lane 1: $100 \mathrm{bp}$ ladder marker; Lane 2: eggplant; Lane 3 : potato; Lane 4 : Japanese radish; Lane 5: komatsuna; Lane 6: spinach; Lane 7: carrot; Lane 8: burdock; Lane 9: onion; Lane 10: Welsh onion; Lane 11: rice; Lane 12: corn; Lane 13: pumpkin; Lane 14: sweet potate; Lane 15: Chinese yam; Lane 16: Jerusalem artichoke; Lane 17: satoimo; Lane 18: shiitake; Lane 19: kuwazuimo; and Lane 20: negative control (no template DNA). (B) Lanes 1-18 are the same as those of (A). Lane 19: negative control (no template DNA).

検出用プライマー対を用いたPCR法の特異性が確認され た。

\section{2. 加熱処理によるPCRへの影響}

食中毒が疑われた場合，原因を特定するために分析する 試料は，惣菜や煮物等調理された食品である場合が多い. そこで，加熱したクワズイモから抽出したDNAを用いて PCRによる検出が可能であるか検討した。 クワズイモの 根茎を水煮 $\left(100^{\circ} \mathrm{C} 15\right.$ 分間および 30 分間) した後, DNA 抽出およびクワズイモ検出用プライマー対を用いて PCR を行った。その結果，加熱したクワズイモからのDNA抽 出およびPCRによる検出が可能であることが電気泳動に より確認できた（Fig. 4). 本法は，クワズイモの摂食が 原因と疑われる食中毒が発生した場合の同定法として, 形 態鑑別やシュウ酸カルシウムの検出が難しい微量の試料に ついても，適用が可能であり，加熱調理の影響を受けにく 


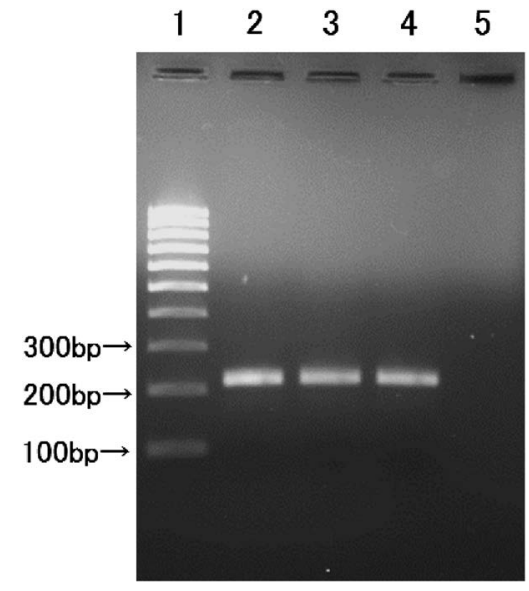

Fig. 4. Agarose gel electrophoresis of PCR-amplification products of untreated and boiled kuwazuimo using the primer pair KUWAZU-Fb and KUWAZU$\mathrm{Ra}$

DNA was extracted from untreated and boiled kuwazuimo for PCR.

Lane 1: 100 bp ladder marker; Lane 2: untreated kuwazuimo; Lane 3: kuwazuimo boiled for $15 \mathrm{~min}$; Lane 4: kuwazuimo boiled for $30 \mathrm{~min}$; and lane 5: negative control (no template DNA).

いことが明らかになった。

\section{DNA塩基配列解析}

DNA シークエンサーを用いて, クワズイモ 5 試料から 得たPCR 産物の塩基配列を解析した。 その結果, 薬用植 物園のクワズイモNo. 1 (Fig. 2, lane 2) のPCR 産物は NCBI の DNA塩基配列データベースに登録されているク ワズイモが持つ標的塩基配列（Acc. no.: AB429315）に一 致した。一方，クワズイモとして購入した試料No. 2-5 （Fig. 2, lane 3-6）の PCR 産物の塩基配列はクワズイモで はなく，シマクワズイモが持つ標的塩基配列（Acc.no.: AB429340）と一致した. なお, クワズイモとシマクワズ イモの塩基配列の相同性は高く, PCR 産物（219 bp）中 の違いは 4 塩基のみである. シマクワズイモは, クワズイ モより耐寒性が低いが5), 小型であるため, 観葉植物とし てクワズイモと称し流通している可能性が高い. クワズイ モ検出用プライマー対を用いることにより, 食中毒の原因 となるクワズイモおよびシマクワズイモを検出することが 可能であった.

\section{ま と め}

クワズイモを同定するための PCR 法を検討した。今回， 新規に作製したクワズイモ検出用プライマー対を用いた PCR法の特異性は高く, クワズイモおよびシマクワズイ モの同定が可能であった。 また，加熱試料に適用可能であ ることも確認されたことから，クワズイモの誤食が疑われ る食中毒の原因特定において, 特に少量かつ調理等された 試料への適用が期待できる。

\section{文献}

1) Toda, M., et al. Trends of plant toxin food poisonings during the past 50 years in Japan. Shokuhin Eiseigaku Zassi (Food Hyg. Saf. Sci.), 55, 55-63 (2014).

2) Shimoi, T., et al. Outbreaks of poisoning by chemical and naturally occurring toxicants in Tokyo, 2013. Tokyoto Kenko Anzen Kenkyu Senta Kenkyu Nenpo (Annual Report of Tokyo Metropolitan Institute of Public Health), 65, 167-172 (2014).

3) Kimura, K., et al. Outbreaks of poisoning due to chemicals and naturally occurring toxicants in Tokyo during 2014. Tokyoto Kenko Anzen Kenkyu Senta Kenkyu Nenpo (Annual Report of Tokyo Metropolitan Institute of Public Health), 66, 165-170 (2015).

4) 日本の野生植物草本第 1 巻単子葉類. 佐竹義輔, 他編. 東 京, 平凡社, 1982, 137p. (ISBN 4-582-53500-6)

5）堀田 満，他. 世界有用植物辞典（オンデマンド版）。堀 田 満, 他編. 東京, 平凡社, 2002, 70p. (ISBN 4-58291059-9)

6) Linder, C. R., et al. A universal molecular method for identifying underground plant parts to species. Molecular Ecology, 9, 1549-1559 (2000).

7）丸山卓郎，他. 遺伝子解析技術を用いた薬用植物基原種の 鑑別. 特産種苗, 16, 70-76 (2013).

8) Masayama, A., et al. Discrimination of mashrooms causing food-poisoning incidents by using DNA sequence analysis. Shokuhin Eiseigaku Zassi (Food Hyg. Saf. Sci.), 53, 237-242 (2012).

9) Matsuoka, T., et al. A detection method for recombinant DNA from genetically modified maize CBH351. Shokuhin Eiseigaku Zassi (Food Hyg. Saf. Sci.), 42, 197-201 (2001). 